\title{
Effect of the Supplementation of Vitamins and Organic Minerals on the Performance of Broilers under Heat Stress ${ }^{1}$
}

Author(s)
Laganá $\mathrm{C}^{2}$
Ribeiro $\mathrm{AML}^{3}$
Kessler $\mathrm{AM}^{3}$
Kratz $\mathrm{LR}^{4}$
Pinheiro $\mathrm{CC}^{4}$
1 Part of the thesis presented by the first
author to Universidade Federal do Rio
Grande do Sul as one of the requisites to
obtain the title of Ph.D. in Animal Science.
2 Researcher APTA Regional/PRDTA Leste
Paulista.
3 Assistant Professor, Dep. Zootecnia - UFRGS-
Porto Alegre - RS.
4 Laboratório de Ensino Zootecnico - UFRGS-
Porto Alegre - RS.

\section{Mail Address}

C Laganá

Caixa Postal 01

13.910-000. Monte Alegre do Sul, SP, Brasil

E-mail: christine@aptaregional.sp.gov.br

Ascorbic acid, dl-alpha-tocopherol, selenium, thermal regulation, zinc.

\section{ABSTRACT}

The objective of this experiment was to evaluate the effect of diet supplementation with vitamins $\mathrm{C}$ and $\mathrm{E}$ and organic minerals $\mathrm{Zn}$ and $\mathrm{Se}$ on the performance of 1 to 35 day-old broilers from, kept under cyclic heat stress $\left(25\right.$ to $\left.32^{\circ} \mathrm{C}\right)$. Four levels of vitamin-mineral supplementation were used (T1-control diet (60/30 IU of vit E for starter and growing diet, respectively, zero vit. C, $80 \mathrm{ppm}$ of inorganic $\mathrm{Zn}, 0.3 \mathrm{ppm}$ of inorganic Se); T2-control diet + $100 \mathrm{UI}$ vit $\mathrm{E}$ and $300 \mathrm{ppm}$ vit $\mathrm{C} / \mathrm{kg}$; T3control diet + $40 \mathrm{ppm} \mathrm{Zn}$ and 0,3 ppm Se/kg; T4-control diet + T2 and T3 levels) and two environments - thermoneutral and cyclic heat stress ( $T N$ and HS) from 14 to 35 days of age. In the period when part of the birds was submitted to HS, from 14 to 35 days, it was observed lower feed intake (FI) and better feed conversion (FC) for HS birds receiving supplementation compared to the group without supplementation. Evaluating the total period, all the types of supplementation provided lower FI and better FC than the control treatment, but not affected weight gain $(W G)$. The supplementation of vitamins $C$ and $E$ and/or organic minerals $\mathrm{Zn}$ and Se improved the performance of birds due to a lower $\mathrm{Fl}$ resulting in better $\mathrm{FC}$, independently on the environment.

\section{Introduction}

Environmental temperature can be considered one of the main physical factors that influence broiler performance, as it has an important effect on feed intake (Cerniglia et al., 1983 e Teeter et al., 1984). This has a direct effect on weight gain and feed conversion ratio, and it is considered as a type of stress. Research studies have often showed that stressed birds require higher vitamin and mineral supply (Coelho \& McNaughton, 1995, Miltenburg, 1999 e El-Boushy, 1988) due to changes in metabolism, to a decrease in feed intake, and to reduced vitamin stability. However, this does not mean that the mere supplementation of vitamins solves problems caused by heat stress (HS) (Ribeiro \& Laganá, 2002). However, few studies were carried out to determine the requirements and the availability of these nutrients under hot conditions.

Vitamins $C$ and $E$ present important metabolic interactions: vitamin $C$ enhances vitamin $E$ antioxidant activity by reducing tocopheroxyl radicals into the active form of vitamin $E$ (Jacob, 1995), or by sparing available vitamin E (Retsky \& Frei, 1995).

Many studies have been carried out on the use of organic trace minerals, as these present higher bioavailability, and are transported more easily and stored for longer periods of time than its inorganic counterparts (Maiorka \& Macari, 2002). Among trace minerals, selenium (Se) has important functions, such as antioxidant, component of enzymes (glutathione peroxidase), and also improves immune response by promoting higher leukocytose and enhanced humoral and cell responses 
against pathogens. In addition, Se is required for normal pancreatic functions (Macpherson, 1994; Combs \& Combs, 1986), including digestive enzyme secretion, thereby improving nutrient digestibility and consequently, performance. Zinc (Zn) is important due to its role in the normal function of the immune system, and its association to enzymes that are essential to maintain the integrity of cells involved in the immune response (Dardenne et al., 1985). $\mathrm{Zn}$ is a cofactor of many essential enzymes, such as lactate dehydrogenase, alkaline phosphatase, and carbonic anhydrase (Maiorka \& Macari, 2002). Zn requirements probably increase during exposure to HS conditions.

Aiming at finding alternatives to reduce heat stress problems in broilers, the objective of the present study was to evaluated the effects of the dietary supplementation of vitamin $C$ and vitamin $E$ and (or) organic zinc and selenium added together (vitamins and minerals) on the performance of broilers submitted to cyclic heat stress $\left(25-32^{\circ} \mathrm{C}\right)$ from 14 to 35 days of age.

\section{MATERIALS AND METHODS}

A total number of 468 day-old male Ross 308 broilers was used. Birds were reared in metal cages with $31 \pm 1{ }^{\circ} \mathrm{C}$ initial temperature, which was gradually decreased to $24 \pm 1^{\circ} \mathrm{C}$ on day 14 . Six birds per cage were randomly distributed into four treatments, according to vitamin and/or trace mineral supplementation: T1 - control diet $(80$ ppm inorganic $\mathrm{Zn} ; 0,3 \mathrm{ppm}$ inorganic Se; $60 \mathrm{lU} / \mathrm{kg}$ vitamin $\mathrm{E}$, included in the vitamin-mineral premix); T2 - vitamin supplementation (100 IU vit. E and 300 ppm vit. C/kg feed); T3 - organic trace mineral supplementation (40 ppm Zn and 0.3 ppm Se/kg feed); and T4 - vitamin and mineral supplementation at the same levels of $\mathrm{T} 2$ + T3.

Vitamin $\mathrm{E}$ was supplemented as $\mathrm{dl}-\mu$ tocopherol acetate $\left(\right.$ Roche $\left.^{\circledR}\right)$, and vitamin $C$ as ascorbic acid $\left(\right.$ Roche $\left.^{\circledR}\right)$. Zinc and selenium were supplemented in an organic form (Zinpro ${ }^{\circledR}$ ).

On day 14, 272 birds (four birds per cage) were selected at random, and distributed into 68 cages, measuring $0.90 \mathrm{~m}^{2}$, located in two different environments: thermoneutral (TNE) and heat stress (HSE), with eight replicates per supplementation type in HSE, and nine replicates per supplementation type in TNE.

HSE was considered as 12 hours at $25^{\circ} \mathrm{C}$, three hours at 25 to $32^{\circ} \mathrm{C}$, six hours at $32^{\circ} \mathrm{C}$, and three hours at 32 to $25^{\circ} \mathrm{C}$ daily, whereas TNE involved daily temperatures of 21 to $25^{\circ} \mathrm{C}$. Air relative humidity was kept at $70 \%$ in both environments.

Birds were fed ad libitum the starter diet from 1 to 21 days of age, and the grower diet from 22 to 35 days of age (Table 1). The only difference in the diet premix between the two phases was the level of vitamin E, which was $60 \mathrm{IU}$ and $30 \mathrm{IU}$, for the starter and grower diets, respectively. Other supplementation levels were kept equal in both phases.

\begin{tabular}{|c|c|c|}
\hline & $\begin{array}{r}\text { Starter diet } \\
\text { (1-21days) }\end{array}$ & $\begin{array}{r}\text { Grower diet } \\
\text { (22-35days) }\end{array}$ \\
\hline \multicolumn{3}{|l|}{ Ingredients } \\
\hline Corn & 56,88 & 60,61 \\
\hline Soybean meal (46CP) & 36,08 & 31,61 \\
\hline Soybean Oil & 2,78 & 3,67 \\
\hline Limestone & 1,43 & 1,39 \\
\hline Dicalcium phosphate & 1,80 & 1,68 \\
\hline Salt & 0,47 & 0,47 \\
\hline Vitamin premix ${ }^{1}$ & 0,05 & 0,05 \\
\hline Mineral premix ${ }^{2}$ & 0,10 & 0,10 \\
\hline Hidroxy analogue (88\%) & 0,23 & 0,25 \\
\hline Choline & 0,03 & 0,03 \\
\hline Coccidiostat & 0,025 & 0,05 \\
\hline \multicolumn{3}{|l|}{ Nutricional levels } \\
\hline $\mathrm{ME}(\mathrm{kcal} / \mathrm{kg})$ & 3000 & 3100 \\
\hline CP $(\%)$ & 21,5 & 19,50 \\
\hline $\mathrm{Ca}$ & 1,0 & 0,95 \\
\hline P avail & 0,45 & 0,42 \\
\hline Lys & 1,25 & 1,14 \\
\hline Met+Cys & 0,90 & 0,83 \\
\hline Zn (ppm) & 80 & 80 \\
\hline Se (ppm) & 0,3 & 0,3 \\
\hline Vit $\mathrm{E}(\mathrm{mg} / \mathrm{kg})$ & 60 & 30 \\
\hline
\end{tabular}

1- Levels calculated based in Rostagno et al. (2000). 2 - Vitamin mix (content per kg/product): Vit.A. $10.000 \mathrm{IU}$; Vit D3 $3.000 \mathrm{IU}$; Vit E 60 mg; Vit K3 3 mg; Vit B1 3 mg; Vit. B2 8 mg; Vit B6 4 mg; Vit B12 0,014 mg; Pantothenic Acid $20 \mathrm{mg}$; Niacin $50 \mathrm{mg}$; Folic Acid $2 \mathrm{mg}$; Biotin $0,15 \mathrm{mg} .3$ - Mineral mix (content per kg/product):: Fe $40 \mathrm{mg}$; Zn 80 $\mathrm{mg}$; $\mathrm{Mn} 80 \mathrm{mg}$; Cu $10 \mathrm{mg}$; 0,7 mg; Se 0,3 mg. 4 -Utilized bioequivalence.

Weight gain, feed intake, and feed conversion ratio were weekly determined until the end of the experimental period (35 days).

Data were submitted to analysis of variance using the GLM (General Linear Models) procedures of SAS (2001) software package. LSMeans test was used to compare treatment means.

\section{RESULTS AND DISCUSSION}

Performance results of the period the birds were kept under thermoneutral conditions (1-14 days of age) are shown in Table 2. No differences in weight gain or feed intake were observed among treatments. 
However, there were significant differences in feed conversion ratio $(p<0.05)$, which was better in birds receiving vitamin-mineral supplementation as compared to those fed the control diet or receiving only vitamin supplementation. The treatment with only mineral supplementation was intermediate.

\begin{tabular}{|c|c|c|c|}
\hline BW(kg) & W G(kg) & $\mathrm{FI}(\mathrm{kg})$ & $\mathrm{FCR}(\mathrm{kg} / \mathrm{kg})$ \\
\hline \multicolumn{4}{|l|}{ Type of supplementation } \\
\hline T1 (control) $\quad 0.412$ & 0.368 & 0.480 & $1.306^{b}$ \\
\hline T2 (control + vit) & 0.363 & 0.476 & $1.316^{b}$ \\
\hline T3 (control + min) 0.409 & 0.366 & 0.470 & $1.287^{\mathrm{ab}}$ \\
\hline T4 (control+vit+min) 0.427 & 0.383 & 0.480 & $1.256^{\mathrm{a}}$ \\
\hline $\begin{array}{ll}p & 0.18\end{array}$ & 0.20 & 0.68 & 0.05 \\
\hline CV (\%) & 7.74 & 6.17 & 5.09 \\
\hline
\end{tabular}

1 - Means in the same column with no common superscript are significantly different.

From 14 to 35 days, there was no interaction between environment and diet on the measured parameters. As shown in Table 3, there was a highly significant effect $(p<0.0001)$ of environment on average weight on day 35. Birds kept in the HSE presented $7.6 \%$ lower weight as compared to those in TNE, which is explained by a reduction in feed intake. Ribeiro et al. (2001) found 9\% lower weight when submitting broilers to cyclic heat stress, but for a longer period of time (21 to 56 days).

\begin{tabular}{|c|c|c|c|}
\hline \multicolumn{4}{|c|}{$\begin{array}{l}\text { Table } 3 \text { - Effect of environment (HS and TN) and type of } \\
\text { supplementation (vitamin and/or mineral) on body weight (BW), } \\
\text { weight gain (WG), feed intake (FI), feed conversion ratio (FCR) of } \\
14 \text { to } 35 \text { d-old broilers. }\end{array}$} \\
\hline BW $(\mathrm{kg})$ & WG (kg) & FI (kg) & R(kg/kg) \\
\hline \multicolumn{4}{|l|}{ Environment } \\
\hline 2,052 & 1,63 & $2,75^{b}$ & $1,69^{a}$ \\
\hline $2.208^{\mathrm{a}}$ & 1.78 & $2.95^{a}$ & $1.66^{b}$ \\
\hline$p \quad<0.0001$ & 0.0001 & $<0.0001$ & 0.05 \\
\hline \multicolumn{4}{|l|}{ Type of supplementation } \\
\hline T1 (control) $\quad 2.123$ & 1.71 & $2.93^{a}$ & $1.719^{b}$ \\
\hline T2 (control + vit) & 1.72 & $2.83^{b}$ & $1.641^{\mathrm{a}}$ \\
\hline T3 (control + $\min ) \quad 2.114$ & 1.69 & $2.82^{b}$ & $1.665^{a}$ \\
\hline T4 (control+vit+min) 2.137 & 1.71 & $2.82^{b}$ & $1.668^{a}$ \\
\hline $\begin{array}{ll}p & 0.73\end{array}$ & 0.69 & 0.002 & 0.01 \\
\hline CV $(\%)$ & 4.6 & 3.3 & 4.1 \\
\hline
\end{tabular}

A $6.8 \%$ reduction was found for feed intake $(p<0.0001)$. Therefore, the environment also influenced weight gain $(p<0.0001)$, which was $8.4 \%$ higher in TNE as compared to HSE, as well as feed conversion ratio. Several authors observed more intense negative effects of HSE on feed intake and weight gain as compared to the present experiment (Oliveira Neto et al., 2000; Lana et al., 2000; Bertechini et al., 1991). As the experimental period ended when birds were 35 days of age, the negative impact of the environment was lower, as the heavier the bird, the more difficult it is to dissipate heat. In addition, cyclic heat stress seems to less harmful to the birds than chronic heat stress (Bonnet et al., 1997).

Supplementation type did not influence bird weight or weight gain $(p<0.73$ and $p<0.69$, respectively). In fact, literature data are conflicting as to mineral supplementation and performance. Bartllet \& Smith (2003), testing different dietary zinc levels (32, 40, and $100 \mathrm{ppm})$, concluded that zinc did not interfere with the performance of 42-day-old broilers under cyclic heat stress $\left(23.9\right.$ to $\left.35^{\circ} \mathrm{C}\right)$. Ferket \& Qhreshi (1992) showed that the supplementation of a vitamin complex (Bcomplex, $A, D$, and $E$ vitamins) in drinking water of broilers submitted to heat stress improved weight gain and feed conversion ratio. Hegazy \& Adachi (2000) observed a significant improvement in weight gain and feed conversion ratio of birds infected with Salmonella, or Salmonella and aflatoxin, and fed diets containing $\mathrm{Zn}(60 \mathrm{ppm})$, and $\mathrm{Zn}+\mathrm{Se}$ (60ppm+1ppm, respectively). However, diets containing only Se (1ppm) reduced performance. On the other hand, the performance of birds not submitted to challenge was not affected by the type of supplementation.

Type of supplementation influenced feed intake $(p<0.002)$. Birds receiving supplementation, independent of type, had lower feed intake. Therefore, supplementation yielded better feed conversion ratio than the control diet $(p<0.01)$. There are only a few studies on this subject, but some authors observed better feed conversion ratio, particularly in layers (Lee et al., 1999; Vathana et al., 2002) and quails (Sahin \& Kucuk, 2001).

When the entire experimental period was taken into account (Table 4), no interaction between environment and diet was observed. However, environment had a negative impact on weight gain, feed intake, and feed conversion ratio of birds submitted to HSE $(p<0.0001)$.

During this period, the results were the same as to those observed during the grower period as to supplementation type. There was no influence on weight gain $(p<0.74)$, but feed intake was affected $(p<0.003)$, with lower feed intake of supplemented birds as compared to those fed the control diet. FCR of supplemented birds was also better $(p<0.003)$, regardless the type of supplementation, which was a result of the lower feed intake. 
The initial hypothesis that heat stress could intensify a marginal vitamin and mineral deficiency, or increase the requirements of these nutrients, was not confirmed, as no interactions were found between these factors. However, there was a beneficial effect of vitamin and mineral supplementation, but there is no direct explanation for the reduction in feed intake is literature. Improvement in nutrient digestibility promoted by some of these minerals and vitamins, and their interrelationships (Sahin \& Kucuk, 2001; Macpherson, 1994; Combs \& Combs, 1986) could improve the efficiency of the use of these nutrients, and therefore, decrease feed intake. According to Thompson \& Scott (1970), all elements of the antioxidant system efficiently interact. This interaction probably starts at nutrient absorption level, and continues throughout their metabolism.

Taking into consideration the better feed conversion ratio promoted by all types of dietary supplementation, and the lower cost of mineral supplementation as compared to vitamin supplementation, the cost-benefit of supplementing only trace minerals would be higher. This advantage could be obtained both in hot and cold seasons.

\begin{tabular}{|c|c|c|c|}
\hline & WG (kg) & $\mathrm{FI}(\mathrm{kg})$ & FCR $(\mathrm{kg} / \mathrm{kg})$ \\
\hline \multicolumn{4}{|l|}{ Environment } \\
\hline HS & $2.01^{\mathrm{t}}$ & $3.225^{b}$ & $1.604^{3}$ \\
\hline TN & $2.16^{\mathrm{a}}$ & $3.425^{3}$ & $1.581^{b}$ \\
\hline$p$ & $<0.0001$ & $<0.0001$ & $<0.0001$ \\
\hline \multicolumn{4}{|c|}{ Type of supplementation } \\
\hline T1 (control) & 2.08 & $3.40^{\equiv}$ & $1.639^{b}$ \\
\hline T2 (control + vit) & 2.10 & $3.30^{b}$ & $1.573^{3}$ \\
\hline T3 (control + min) & 2.07 & $3.28^{b}$ & $1.589^{\mathrm{a}}$ \\
\hline T4 (control+vit+min) & 2.09 & $3.28^{b}$ & $1.569^{\mathrm{a}}$ \\
\hline $\mathrm{p}$ & 0.74 & 0.003 & $<0.003$ \\
\hline CV $(\%)$ & 4.3 & 3.1 & 2.8 \\
\hline
\end{tabular}

\section{CONCLUSIONS}

The supplementation of vitamins $E$ and $C$ and of the organic trace minerals $\mathrm{Zn}$ and Se did not influence weight gain of broilers reared in thermoneutral or heat stress environment. However, performance was improved, promoting lower feed intake, which resulted in better feed conversion ratio, independent of environmental temperature. Due to cost considerations, it is suggested that organic trace mineral supplementation should be used instead of vitaminmineral supplementation.

\section{REFERENCES}

Bartlett JR, Smith MO. Effects of different levels of zinc on the performance and Immunocompetence of broilers under heat stress. Poultry Science 2003; 82(10):1580-1588.

Bertechini AG, Rostagno HS, Silva MA. Efeitos da temperatura ambiente e nível de energia da ração sobre o desempenho e a carcaça de frangos de corte. Revista Brasileira de Zootecnia 1991; 3(1):219-229.

Bonnet S, Geraert PA, Lessire M. et al. Effect of high ambient temperature on feed digestibility in broilers. Poultry Science 1997; 76(6):857-863.

Cerniglia GJ, Herbert JA, Watts AB. The effect of constant ambient temperature and ration on the performance of sexed broilers. Poultry Science 1983; 62(5):746-754.

Coelho MB, McNaughton JL. Effect of composite vitamin supplementation on broilers. Journal of Applied Poultry Research 1995; 4(2):219-229.

Combs GF, Combs SB. The Role of Selenium in Nutrition. London: Academic Press; 1986. 180p.

Dardenne M, Savino W, Borrih S. et al. A zinc dependent epitope of the molecule of thymulin, a thymic hormone. Proceedings of the National Academy of Sciences 1985; 82:7035.

Deaton JW, Reece FN, Vardaman TH. The effect of temperature and density on broiler performance. Poultry Science 1968; 47(2):293300.

Deyhim F, Teeter RG. Vitamin withdrawal effects on performance, carcass composition, and tissue vitamin concentration of broilers exposed to various stress types. Journal of Applied Poultry Research 1993; 2(2):347-355.

El-Boushy AR. Vitamin E affects viability, immune response of poultry. Feedstuffs 1988; 60(4):20-26.

Ferket PR, Qureshi MAA. Performance and immunity of heat-stressed broilers fed vitamin- and electrolyte supplemented drinking water. Poultry Science 1992; 71(1):88-97.

Hegazy SM, Adachi Y. Comparison of the effects of dietary selenium, zinc and selenium and zinc supplementation on growth and immune response between chick groups that were inoculated Salmonella and Aflatoxin or Salmonella. Poultry Science 2000; 79:331-335

Jacob RA. The integrated antioxidant system. Nutrition Research 1995; 15(4):755-766

Lana GRQ, Rostagno HS, Albino LFT. et al. Efeito da temperatura ambiente e da restrição alimentar sobre o desempenho e a composição da carcaça de frangos de corte. Revista Brasileira de 
Zootecnia 2000; 29(4):1117-1123.

Maiorka A, Macari M. Absorção de minerais In: Macari M; Furlan, RL, Gonzales E. Fisiologia aviária aplicada a frangos de corte. 2ed. Jaboticabal: Funep/Unesp; 2002. p. 167-174.

Macpherson A. Selenium, vitamin E and biological oxidation. In: Cole DJ, Garnsworthy PJ. Recent Advances in Animal Nutrition. Oxford: Butterworth and Heinemann; 1994. p. 3-30.

Miltenburg G. Avicultura moderna. Avicultura Profesional 1999; 17(9):33-35.

Oliveira Neto AR, Oliveira RFM, Donzele JL. Metabolizable energy level for broilers from 22 to 42 days of age maintained under thermoneutral environment. Revista Brasileira de Zootecnia 2000; 29(4):1132-1140.

Pardue SL, Thaxton JP, Brake J. Role of ascorbic acid in chicks exposed to high environmental temperature. Journal of Applied Physiology 1985; 58(9):1511-1516.

Pardue SL, Thaxton JP. Ascorbic acid in poultry: a review. World's Poultry Science 1986; 42(2):107-123.

Retsky KL, Frei B. Vitamin C prevents metal ion-dependent initiation and propagation of lipid peroxidation in human low-density lipoprotein. Biochemistry and Biophysics 1995; 3(1257):279-287.

Ribeiro AML, Penz AM, Teeter R. Effects of 2-hydroxy-4(methylthio)butanoic acid and DL-Methionine on broiler performance and compensatory growth after exposure to two different environmental temperatures. Journal. Applied Poultry Research 2001; 10(4):419-426.
Ribeiro AML, Laganá C. Estratégias nutricionais para otimizar a produção de frangos de corte em altas temperaturas. In: Encontro Internacional dos Negócios da Pecuária; 2002; Cuiabá. Resumos... Cuiabá : ENIPEC; 2002. 1 CD-ROM

Rostagno HS, Albino LFT, Donzele JL. et al. Tabelas Brasileiras para aves e suínos. Composição de alimentos e exigências nutricionais. Viçosa: UFV; 2000

Sahin K, Kucuk O. Effects of vitamin E and selenium on performance, digestibility of nutrients, and carcass characteristics of Japanese quails reared under heat stress $\left(34^{\circ} \mathrm{C}\right)$. Journal of Animal Physiology and Animal Nutrition 2001; 85(2):342-348

SAS statistic analysis system. Painless Windows, a handbook for SAS users. 2nd ed. Guelph: Jodie Gilmore; 2001

Summers JD. Heat stress. Ontaro: Poultry Industry Centre; 1994. 6p. (Tech-Info, 6).

Teeter RG, Smith MO, Murray E. Force feeding methodology and equipment for poultry. Poultry Science 1984; 63(4):573-575.

Tengerdy RP. Vitamin E, immune response, and disease resistance. Annals of the New York Academy of Sciences 1989; 570(2):335344.

Thompson JN, Scott ML. Impaired lipid and vitamin E absorption related to atrophy of the pancreas in selenium-deficient chicks. Journal of Nutrition 1970; 100(3):797-809. 
